\title{
EFFECT OF CONTROL TREATMENTS ON THE ROOT RESERVES OF CALIFORNIAN THISTLE (CIRSIUM ARVENSE)
}

\author{
R.B. MITCHELL and L.T. DAVIS \\ Agresearch, Invermay Agricultural Centre \\ Private Bag 50034, Mosgiel.
}

\begin{abstract}
In autumn 1994, 3 month old Californian thistle plants grown from seed were transplanted at regular spacings into a ryegrass/white clover sward. Seven treatments including three topping treatments, the herbicides clopyralid and MCPB, and a mycoherbicide Sclerotinia sclerotiorum, were applied to thistle foliage the following summer. Treatment effects on root mass and bud production were measured in December 1995. Clopyralid and S. sclerotiorum reduced dry root weight relative to control $95 \%$ and $60 \%$ respectively and also reduced the number of root buds and shoots. MCPB had little effect on root weight but reduced root bud numbers by $60 \%$. Thistles topped twice also showed reductions in root weight and shoot numbers.
\end{abstract}

Keywords: Californian thistle, topping, chemical control, Sclerotinia

\section{INTRODUCTION}

Californian thistle (Cirsium arvense L.) is a major problem in agricultural countries, including New Zealand (Holmet al. 1977). Above ground shoots arise from adventitious buds that are produced on an extensive root system (Moore 1975; Hodgson 1968). The roots contain abundant food supplies that endow the plant with the capacity for vigorous regenerative growth. This favours plant spread but makes thistle eradication difficult. Thistles take up resources and space of desirable pasture plants and the prickly nature of the mature shoots inhibits stock grazing close to the plant's base resulting in loss of both crop and pasture production (Trumble and Kok 1982; Oswald 1985). The presence of thistles in hay leads to rejection of fodder by stock (Oswald 1985).

Two of the most widely used methods to reduce Californian thistle density in pasture are mowing and herbicide application. Both have varying degrees of effectiveness depending on the time and number of mowings or type of herbicide applied (Donald 1990). Two commonly used translocated herbicides which control a range of broadleaved weeds are clopyralid and MCPB (Worthing and Walker 1987; Donald 1990). In plants, clopyralid accumulates in areas of rapid growth (meristems) and metabolic sinks (seeds, storage organs) (Donald 1990). MCPB is effective only in plants capable of translocating and oxidising this herbicide to MCPA (Worthing and Walker 1987).

Recently the mycoherbicide Sclerotinia sclerotiorum (Lib.) de Bary has been shown in trial work to reduce Californian thistle cover in pastures (Brosten and Sands 1986; Bourdôt et al.1993). Mycelium of this soil-borne fungus attacks the thistles lower stems and roots and produces enzymes that degrade plant cell walls.

This study investigated the effect of time and frequency of topping, herbicide application and $S$. sclerotiorum application on the growth of roots and shoots originating from individual Californian thistle plants growing in pasture. 


\section{METHODS}

In April 1994, thistles raised from seed in a glasshouse were planted in groups of 3 (reduced to one on 11th August 1994) at 10m x 10m spacings throughout two adjacent Manawa ryegrass (Lolium perenne x L. multiflora L.) / white clover (Trifolium repens L.) pastures. During the establishment phase, all individual thistle plants were protected from stock using steel mesh cages. The cages were removed on 18th January 1995 and all plants were then open to grazing. In summer 1995, individual plants were subjected to one of seven treatments:

1. Untreated.

2. Topped at the pre-bolting stage (5 January 1995) and repeated when the leaf spines hardened (5 March 1995).

3. Topped at bolting (6 March 1995).

4. Topped at late bolting (27 March 1995).

5. Clopyralid applied (plants wiped two ways with a hockey stick weed wiper) during early bolting (17 January 1995) using $7.5 \mathrm{~g} /$ litre of water.

6. MCPB applied as a spray during bolting using $5 \mathrm{~g} /$ litre of water (7 March 1995).

7. Sclerotinia sclerotiorum applied as mycelium on kibbled wheat kernels following rain (4 January 1995). Fifty grams of kernels, approximately 770,000 colony forming units, were applied $/ \mathrm{m}^{2}$ (Bourdôt et al.1995).

Each treatment was applied to 6 individual plants, except topping at the bolting stage which was replicated 12 times. For topped treatments, thistles were trimmed with secateurs to $1-2 \mathrm{~cm}$ above soil surface which removed all thistle foliage. Pastures were grazed periodically by sheep, but often became rank $(>30 \mathrm{~cm})$ before grazing.

Between late November and early December 1995, the numbers of aerial shoots arising from each plant were counted, their height and diameter measured and the distance of new shoots from the parent plant recorded. Approximately $50 \%$ of these shoots had been grazed by stock and were excluded from the analyses. Root mass per plant was determined by digging roots to a depth of $60 \mathrm{~cm}$ and hand separating roots from soil. A subsample of root mass (up to $20 \mathrm{~g}$ depending on plant size) was placed in $80 \%$ lactic acid at $60^{\circ} \mathrm{C}$ for between 7 and 12 days to allow identification and counting of adventitious buds. The remaining roots were weighed and dried at $80{ }^{\circ} \mathrm{C}$ for 12 hours to determine dry matter (DM).

Analysis of variance was performed on the dry weight values. Shoot height, diameter and distance from the parent plant were analysed using REML (Patterson and Thompson 1971). The remaining parameters were analysed using generalised linear models ( ${ }^{\mathrm{C}}$ Cullagh and Nelder 1989), with a normal distribution for the root length data, and a Poisson distribution with a log link function for bud and shoot numbers. The assessment of an overall treatment effect was carried out using the F statistic. If this was significant, differences between means were compared relative to their standard errors as (unadjusted) t statistics.

\section{RESULTS}

Roots from plants topped at the bolting and late bolting stage of growth had significantly higher mean dry weights than plants treated with either S. sclerotiorum or clopyralid $(\mathrm{P}<0.05)$, but were not significantly different from either the control or MCPB treatments (Table 1). Topping at the late bolting stage resulted in greater dry weight than topping at the pre-bolting stage $(\mathrm{P}<0.05)$ (Table 1$)$. The clopyralid treatment showed a 95\% reduction, and the pre-bolting topping and S. sclerotiorum application approximately $50 \%$ decreases in DM relative to the control $(\mathrm{P}<0.01)$ (Table 1).

There was no significant difference in root length between any of the treatments or between any treatment and the control plants for root length per $20 \mathrm{~g}$ weight taken for the bud count (Table 1).

Both herbicides were associated with significant reductions in the number of root buds relative to all other treatments $(\mathrm{P}<0.05)$. S. sclerotiorum treated plants showed a similar reduction in root buds compared to all other treatments $(\mathrm{P}<0.05)$ except 'prebolting' (Table 1). 
TABLE 1: Californian thistle root dry weights (g), root lengths per $20 \mathrm{~g}$ fresh weight, and number of buds per $1.6 \mathrm{~m}$ of root after topping and herbicide treatments.

\begin{tabular}{lccc}
\hline Treatment & $\begin{array}{c}\text { Root dry } \\
\text { weight }\end{array}$ & Root length & $\begin{array}{c}\text { No. of } \\
\text { buds }\end{array}$ \\
\hline Control & 3.95 & 253 & 18.4 \\
Topped - pre-bolting & 2.08 & 240 & 15.5 \\
stage \& repeated & & & \\
Topped - bolting stage & 5.61 & 243 & 16.4 \\
Topped - late bolting stage & 7.25 & 239 & 22.2 \\
Clopyralid & 0.21 & 311 & 3.5 \\
MCPB & 3.37 & 187 & 7.4 \\
S. sclerotiorum $^{1}$ & 1.61 & 239 & 11.6 \\
LSD 1 & 3.45 & & \\
LSD 2 & 3.97 & 133 & 5.66 \\
LSD 3 & & 100 & 5.25 \\
LSD 4 & & ns & $*$ \\
Significance of overall & $* *$ & & \\
treatment effect & & &
\end{tabular}

${ }^{1}$ median LSD for root dry weight comparisons between plants topped at the bolting stage and any other treatment as this treatment has 12 replicates compared to 6 for other treatments.

2 median LSD for root dry weight comparisons not involving plants topped at the bolting stage.

${ }^{3}$ median LSD for root length and no. of buds comparisons between clopyralid and any other treatment.

${ }^{4}$ median LSD for root length and no. of buds comparisons not involving clopyralid.

5 ns indicates not significant $(\mathrm{P}>0.05)$; * significant $(\mathrm{P}<0.05)$; ** significant $(\mathrm{P}<0.01)$.

TABLE 2: Numbers of aerial shoots, shoot height $(\mathrm{cm})$, shoot diameter $(\mathrm{cm})$, and mean distance of new shoots from parent plants $(\mathrm{cm})$ of Californian thistle after topping and herbicide treatments.

\begin{tabular}{|c|c|c|c|c|}
\hline Treatment & $\begin{array}{l}\text { No. of } \\
\text { shoots }\end{array}$ & $\begin{array}{l}\text { Shoot } \\
\text { height }\end{array}$ & Diameter & $\begin{array}{c}\text { Distance } \\
\text { from } \\
\text { parent }\end{array}$ \\
\hline Control (grazed) & 6.7 & 4.4 & 0.281 & 8.2 \\
\hline \multicolumn{5}{|l|}{ Topped - pre-bolting } \\
\hline stage \& repeated & 3.7 & 7.0 & 0.289 & 8.4 \\
\hline Topped - bolting stage & 6.9 & 12.5 & 0.410 & 7.4 \\
\hline Topped - late bolting stage & 8.3 & 16.3 & 0.423 & 9.1 \\
\hline Clopyralid & 0.8 & 4.6 & 0.154 & 4.3 \\
\hline MCPB & 4.3 & 18.9 & 0.444 & 8.9 \\
\hline S. sclerotiorum & 3.2 & 7.4 & 0.322 & 13.9 \\
\hline $\mathrm{LSD}^{1}$ & 2.68 & 13.55 & 0.199 & 6.26 \\
\hline $\mathrm{LSD}^{2}$ & 2.72 & 8.41 & 0.127 & 6.59 \\
\hline $\begin{array}{l}\text { Significance of over } \\
\text { all treatment effect }\end{array}$ & ns & $* * *$ & $*$ & ns \\
\hline
\end{tabular}


Clopyralid treated plants produced fewer shoots than all other treatments $(\mathrm{P}<0.01)$ while $S$. sclerotiorum treated plants and those cut at the pre-bolting stage had fewer shoots than all treatments except clopyralid $(\mathrm{P}<0.01)$ (Table 2$)$.

The new shoots from plants cut at the bolting and late bolting stages and those treated with MCPB were significantly taller than the control plants and plants topped at pre-bolting $(\mathrm{P}<0.05)$ (Table 2). The late bolting and MCPB treatments were also associated with taller shoots than $S$. sclerotiorum $(\mathrm{P}<0.05)$ (Table 2$)$.

Clopyralid treated plants had smaller shoot diameters than all other treatments while topping treatments at bolting, and late bolting and the MCPB treatment showed significantly greater diameters compared to other treatments $(\mathrm{P}<0.01)$ (Table 2$)$.

New shoots arising from the $S$. sclerotiorum treated plants were located further from the parent plant than the shoots for the other treatments $(\mathrm{P}<0.05)$ (Table 2$)$. There were no significant differences between other treatments.

\section{DISCUSSION}

Plants topped at pre-bolting and again later showed a reduction in root weight and shoot number to approximately half that of the control treatment. Plants topped only once showed an increase in root mass relative to the control plants and the emerged shoots were more vigorous. This is consistent with other studies showing that frequent mowing is more effective in controlling thistles than infrequent mowing (Moore 1975; Donald 1990; Welton et al. 1929). In this study cutting the shoots only once had little effect on the number of root buds. However, by removing the photosynthetic tissue of the plant, accumulation of food reserves in the roots was reduced. These reserves were depleted as new shoots were produced and it seems probable that the plant would be unable to produce as many, or as vigorous shoots, as when the reserves were high. The more frequent the defoliation, the greater the reduction of root reserves and therefore the more adverse the effect on the plant. This has been demonstrated with topping followed by repeat grazings (Mitchell and Abernethy 1993, 1995).

Clopyralid had the greatest overall adverse effect on the plants; this is similar to the findings of O'Sullivan and Kosstaz (1982). MCPB gave a different and less dramatic effect than clopyralid. The mean root mass in this treatment was relatively unaffected but the number of root buds and shoots were reduced. The shoots that did emerge were more vigorous with significantly greater height and diameter than control plants. Meeklah and Mitchell (1984) found MCPB to give poor control of Californian thistle but Hartley et al. (1984) found a single application gave a 93\% reduction in shoot numbers. Bourdôt et al. (1995) suggested that conflicting results reflected differences between the populations' susceptibility to herbicides. Four subspecies of $C$. arvense are recognised in North America and variation in response to herbicides occurs (Donald 1990).

S. sclerotiorum resulted in smaller effects than clopyralid, showing reductions in root dry weight and the number of shoots. Similar results were found by Bourdôt $e t$ al. (1995).

Extremely dry weather conditions and subsequent lack of soil moisture during the summer and autumn of 1995 slowed thistle growth; plants were drought stressed at the time of application with few thistles reaching the budding stage.

The effect of the herbicides, in particular clopyralid, may have been enhanced by low shoot densities. At the time of application only low numbers of shoots were arising from each plant so all shoots were able to be treated. Under more moist conditions shoot density is greater and a number of shoots would be shielded from direct contact with the weed wiper. Although it has been shown that clopyralid is translocated to the roots (Devine and Vanden Born 1985; Turnball and Stephenson 1985) most work has been performed on single shoots and it is unclear if clopyralid is translocated along roots to other shoots.

The root sampling depth of $60 \mathrm{~cm}$ was similar to that used in previous Californian thistle trials. However in this trial, in all treatments except clopyralid, insignificant amounts of the roots of some thistle plants extended below $60 \mathrm{~cm}$ so root weight was probably under estimated. 


\section{ACKNOWLEDGEMENTS}

This work was funded by the Foundation for Science, Research and Technology and by an AgResearch summer student research bursary. The authors would like to thank Dr.R.J. Littlejohn for statistical analyses and C.M Ferguson for helpful comment.

\section{REFERENCES}

Bourdôt, G.W., Harvey, I.C., Hurrel, G.A. and Alexander, R.T., 1993. An experimental mycoherbicide utilising Sclerotinia sclerotiorum controls pasture populations of Cirsium arvense in Canterbury. Proc. 46th N.Z. Plant Prot. Conf.: 251-256.

Bourdôt, G.W., Harvey, I.C., Hurrell, G.A. and Saville, D.J., 1995. Demographic and biomass production consequences of inundative treatment of Cirsium arvense with Sclerotinia sclerotiorum. Biocont. Sci. and Tech. 5: 11-25.

Brosten, B. and Sands, D., 1986. Field trials of Sclerotinia sclerotiorum to control Canada thistle (Cirsium arvense). Weed Sci. 34: 377-380.

Devine, M.D. and Vanden Born, W.H., 1985. Absorption, translocation, and foliar activity of clopyralid and chlosulfuron in Canada thistle (Cirsium arvense). Reviews of Weed Sci. 5: 193-250.

Donald, W.W., 1990. Management and control of Canada thistle (Cirsium arvense). Reviews of Weed Sci. 5: 193-250.

Hartley, M.J., Lyttle, L.A. and Popay, A.I., 1984. Control of Californian thistle by grazing management. Proc. 37th N.Z. Weed and Pest Control Conf.: 24-27.

Hodgson, J.M., 1968. The nature, ecology and control of Canada thistle. US. Department of Agriculture Technical Bulletin. 1386. 32pp.

Holm, L.G., Plunknett, D.L., Pancho, J.V. and Herberger, J.P., 1977. Cirsium arvense (L.) Scop. Pp 217-224 In: The World's Worst Weeds- Distribution and Biology. East-West Centre, University of Hawii.

$\mathrm{M}^{\mathrm{C}}$ Cullagh, P. and Nelder, J.A., 1989. Generalised Linear Models. 2nd edition. Chapman and Hall, London.

Meeklah, F.A. and Mitchell, R.B., 1984. Evaluation of herbicides for control of Californian thistle. Proc. 37th N.Z. Weed and Pest Control Conf:: 20-23.

Mitchell,R.B. and Abernethy, R.J.,1993. Integrated management of Californian thistle in pasture. Proc. 46th N.Z. Plant Prot. Conf.: 278-281.

Mitchell, R.B. and Abernethy, R.J.,1995. The effect of topping and repeat grazings on Californian thistle and pasture production.Proc. 48th N.Z. Plant Prot. Conf.: 189193.

Moore R.J., 1975. The biology of Canadian weeds. 13. Cirsium arvense (L)Scop.Can. J. Plant Sci. 55: 1033-1048.

O'Sullivan, P.A and Kossatz, V.C., 1982. Selective control of Canada thistle in rapeseed with 3,6-dichloropicolinic acid. Can. J. Plant Sci. 62: 989-993.

Oswald, A.K., 1985. Impact and control of thistles in grassland. Pp 128-136In: Weeds Pests and Diseases of Grassland and Herbage Legumes, Proceedings of a symposium held at the University of Nottingham 10-12 April 1985. British Crop Protection Council, 1985.

Patterson, H.D. and Thompson, R., 1971. Recovery of inter-block information when block sizes are unequal. Biometrika, 58: 545-554.

Trumble, J.T. and Kok, L.T., 1982. Integrated pest management techniques in thistle suppression in pastures of North America. Weed Res. 22: 345-359.

Turnbull, G.C. and Stephenson, G.R., 1985. Translocation of clopyralid and 2,4-D in Canada thistle (Cirsium arvense). Weed Sci. 33: 143-147.

Welton, F.A, Morris, V.H. and Hartzler, A.J., 1929. Organic food reserves in relation to the eradication of Canada thistle. Ohio Agricultural Experimental Station Bulletin 441. 25pp.

Worthing, C.R. and Walker, S.B., 1987. The Pesticide Manual. A World Compendium. 8th edition. Pp 3215-3216, 7810. 